\title{
Gastric secretion after massive small bowel resection
}

\author{
COLIN W. O. WINDSOR, J. FEJFAR, AND D. A. K. WOODWARD \\ From the Department of Surgery, Queen Elizabeth Hospital, Birmingham
}

SUMMARY This paper confirms that gastric hypersecretion can occur in man and dogs after massive intestinal resection. The assumption, made by others, that hypersecretion in the clinical situation is similar to that observed in dogs is challenged.

An acute hypersecretory state occurred in eight of 19 patients after massive intestinal resection. This was apparent as an increased rate of basal secretion. It was usually transient and unrelated to the length of intestine resected. A correlation was noticed between hypersecretion and jaundice in the immediate postoperative period. Histamine release after acute hepatic injury was postulated as the cause of the hypersecretion.

By contrast a chronic gastric hypersecretory state was demonstrated in dogs after massive intestinal resection. The rate of basal secretion was not significantly altered. The increased daily acid output was shown to be due to prolonged and enhanced response to food. The cause was thought to be loss of inhibitory agents, such as enterogastrone, normally released by the small intestine when in contact with food. The rationale of performing vagotomy and pyloroplasty at the same time as the intestinal resection is questioned.

A possibly important complication of massive small bowel resection, gastric hypersecretion, has recently been described in man (Frederick, Sizer, and Osborne, 1965; Osborne, Frederick, Sizer, Blair, Cole, and Thum, 1966; Aber, Ashton, Carmalt, and Whitehead, 1967; Grundberg, Lopez, and Dragstedt, 1967). Other workers have demonstrated hypersecretion of acid from Heidenhain pouches in dogs after massive intestinal resection (Landor and Baker, 1964; Westerheide, Elliott, and Hardacre, 1965; Reul and Ellison, 1966; Kerr, Elliott, and Endahl, 1968).

In patients neither the incidence nor the characteristics of the hypersecretion have been described, although it has been evident as massive aspirations starting in the immediate postoperative period. The dog studies reported in the literature have constantly shown an increase in the daily acid output from gastric pouches; however, estimations of the basal rate of secretion and histamine responses have failed to show significant changes after resection leaving the cause of the increased acid output speculative.

In this paper 19 patients have been studied after massive intestinal resection, that is, by definition, resection of more than a third or $300 \mathrm{~cm}$ of small intestine (Haymond, 1935; Pullan, 1959). In addition eight dogs, five with Heidenhain pouches and three with Pavlov pouches, have had gastric investigations before and after $75 \%$ intestinal resection. The results show that the hypersecretion seen in patients after resection has different characteristics to that observed in dogs. The possible explanation of these differences is discussed.

\section{MATERIALS AND METHODS}

Nineteen patients aged between 12 and 68 years admitted to hospitals in the Birmingham region between 1963 and 1968 have been studied. All had massive intestinal resections, for the reasons shown in Table I. Seven have had gastric function studies performed since resection. The data from the immediate postoperative period have been retrospective in all but four instances. In four patients no record existed of the aspirate; however, questioning of the surgeons concerned confirmed that hypersecretion was not a problem in these particular patients.

The normal basal rate of gastric secretion in man is up to $1,500 \mathrm{ml}$ per day containing up to $120 \mathrm{~m}$-equiv of hydrochloric acid (Wright, 1952; Dragstedt, Woodward, Storer, Oberhelman, and Smith, 1950; Allen, 1959). Surgery normally produces a slight increase in basal secretion (Dragstedt, Ragins, Dragstedt, and Evans, 1956). In order to define normal aspirations, data were 
collected from 50 patients undergoing uncomplicated abdominal surgery. The peak daily volume of aspirates ranged between 100 and $1,500 \mathrm{ml}$ per day with a mean of $750 \mathrm{ml} /$ day. For these reasons aspirates in excess of 1.5 litres/day, especially if containing more than 120 m-equiv of $\mathrm{HCl}$, have been judged to be abnormal. These criteria may be open to criticism but have provided a baseline necessary to define a hypersecretory state.

Gastric function studies were performed using subcutaneous pentagastrin $(6 \mu \mathrm{g} / \mathrm{kg}$ body weight). Studies were made six weeks to two years after resection.

Eight mongrel bitches weighing between 16 and $26 \mathrm{~kg}$ were used for the studies of gastric secretion. Heidenhain pouches were made by the method of De Vito and Harkins (1959) and the Pavlov pouches by the method described by Perry, Salmon, Griffen, Root, and Wangensteen (1959). The completeness of vagal innervation was checked by insulin testing.

After recovery from the pouch operations base-line studies were made for a period of one month. Then a $75 \%$ resection of the small intestine was performed with preservation of the ileocaecal valve; the resection left the duodenum and first part of the jejunum intact. Pouch collections were started one week after this operation and continued for at least a month. All dogs were fed a standard diet throughout the experiment with sodium and potassium supplements. The following tests of gastric function were made: (1) 24-hour collections of pouch secretion; (2) basal secretory rate, estimated at least four times in each phase of the experiment after a 31-hour fast; (3) postcibal acid output, measured hourly for six hours after a standard meat meal; (4) maximal acid output, determined in response to an injection of histamine phosphate $(0.1 \mathrm{mg} / \mathrm{kg}$ body weight). At least two tests were performed in each phase of the experiment.

Hydrochloric acid was measured in all specimens by titration with $\mathrm{NaOH}$ to $p \mathrm{H} 7$ using autotitration equipment. ${ }^{1}$

\section{RESULTS}

CLINICAL STUDY Table I shows the peak daily aspirates in the 19 patients. Eight had aspirates in excess of 1.5 litres per day, the peak volumes being between 1.9 and 4.1 litres per day (mean 3.1 litres). In the remaining 11 patients the peak volumes were below 1.5 litres; by the criteria laid down these aspirates were not abnormal.

Hydrogen ion losses in the aspirates were measured on four patients (Table II) and ranged between $62.5 \mathrm{~m}$-equiv/day and $480 \mathrm{~m}$-equiv/day. In all instances aspirates were bile stained, suggesting that some acid had been neutralized, yet in three the output was in excess of that expected from duodenal ulcer patients. Figure 1 shows the daily aspirates of a typical patient (case 1).

In two other patients with a hypersecretory trend (cases 4 and 6 ) the $p H$ of aspirates was less than

${ }^{1}$ Radiometer Copenhagen.
TABLE I

CLINICAL DATA

\begin{tabular}{|c|c|c|c|c|}
\hline $\begin{array}{l}\text { Case } \\
\text { No. }\end{array}$ & Diagnosis & $\begin{array}{l}\text { Length of } \\
\text { Small Bowel } \\
\text { Remaining } \\
(\mathrm{cm})\end{array}$ & Outcome & $\begin{array}{l}\text { Maximum } \\
\text { Aspiration } \\
\text { (ml/day) }\end{array}$ \\
\hline 1 & $\begin{array}{l}\text { Superior mesenteric } \\
\text { artery embolus }\end{array}$ & 40 & $\begin{array}{l}\text { Died twelfth } \\
\text { day }\end{array}$ & 4,160 \\
\hline $\begin{array}{l}2 \\
3\end{array}$ & $\begin{array}{l}\text { Pelvic carcinoma } \\
\text { Superior mesenteric } \\
\text { artery embolus }\end{array}$ & $\begin{array}{r}200 \\
40\end{array}$ & $\begin{array}{l}\text { Survived } \\
\text { Died sixth } \\
\text { day }\end{array}$ & $\begin{array}{l}3,800 \\
2,319\end{array}$ \\
\hline 4 & $\begin{array}{l}\text { Superior mesenteric } \\
\text { artery embolus }\end{array}$ & 300 & $\begin{array}{l}\text { Died sixth } \\
\text { day }\end{array}$ & 2,950 \\
\hline 5 & $\begin{array}{l}\text { Superior mesenteric } \\
\text { artery thrombosis }\end{array}$ & 120 & Survived & 3,590 \\
\hline 6 & $\begin{array}{l}\text { Superior mesenteric } \\
\text { vein thrombosis }\end{array}$ & 400 & Survived & 3,800 \\
\hline 7 & $\begin{array}{l}\text { Superior mesenteric } \\
\text { artery embolus }\end{array}$ & 90 & $\begin{array}{l}\text { Died fifth } \\
\text { day }\end{array}$ & 3,010 \\
\hline 8 & $\begin{array}{l}\text { Superior mesenteric } \\
\text { vein thrombosis }\end{array}$ & 150 & Survived & 1,985 \\
\hline 9 & $\begin{array}{l}\text { Superior mesenteric } \\
\text { artery thrombosis }\end{array}$ & 15 & $\begin{array}{l}\text { Died seventh } \\
\text { day }\end{array}$ & 1,432 \\
\hline 10 & $\begin{array}{l}\text { Superior mesenteric } \\
\text { vein thrombosis }\end{array}$ & 20 & Survived & 394 \\
\hline 11 & $\begin{array}{l}\text { Superior mesenteric } \\
\text { artery embolus }\end{array}$ & 40 & Survived & No record \\
\hline 12 & Trauma & 200 & $\begin{array}{l}\text { Survived } \\
\text { Survived }\end{array}$ & $\begin{array}{c}190 \\
\text { No record }\end{array}$ \\
\hline $\begin{array}{l}14 \\
15\end{array}$ & Internal strangulation & $\begin{array}{l}120 \\
400\end{array}$ & Survived & No record \\
\hline 15 & $\begin{array}{l}\text { Internal strangulation } \\
\text { Superior mesenteric } \\
\text { artery embolus }\end{array}$ & $\begin{array}{r}400 \\
90\end{array}$ & $\begin{array}{l}\text { Survived } \\
\text { Survived }\end{array}$ & $\begin{array}{l}\text { No record } \\
1,190\end{array}$ \\
\hline $\begin{array}{l}17 \\
18\end{array}$ & $\begin{array}{l}\text { Mesenteric tumour } \\
\text { Superior mesenteric } \\
\text { artery embolus }\end{array}$ & $\begin{array}{r}120 \\
5\end{array}$ & $\begin{array}{l}\text { Survived } \\
\text { Survived }\end{array}$ & $\begin{array}{l}500 \\
\text { Small } \\
\text { quantities }\end{array}$ \\
\hline 19 & $\begin{array}{l}\text { Superior mesenteric } \\
\text { artery embolus }\end{array}$ & 40 & Survived & 500 \\
\hline
\end{tabular}

TABLE II

PEAK DAILY HYDROCHLORIC ACID LOSSES IN GASTRIC ASPIRATES

Patient No.

Peak Daily Loss ( $\mathrm{HCl}$ m-equiv/day)

\begin{tabular}{lc}
\hline 1 & 480 \\
2 & 238 \\
3 & $62 \cdot 5$ \\
7 & 240
\end{tabular}

2. In the remaining two patients there were no data on the hydrogen ion losses.

On this evidence it is suggested that all eight patients with massive aspirates had a hypersecretory state. As this was evident in the immediate postoperative period, with restriction of oral input to a few hundred millilitres of water per day, it is likely that the hypersecretion is due to an increase of the basal rate of acid secretion.

Length of resected intestine Nine patients had resections leaving $90 \mathrm{~cm}$ or less of small intestine. Three developed hypersecretion, six did not (Table 1). This suggests that factors other than the resection may be responsible for the hypersecretion.

Onset and duration Figure 2 shows the time of 


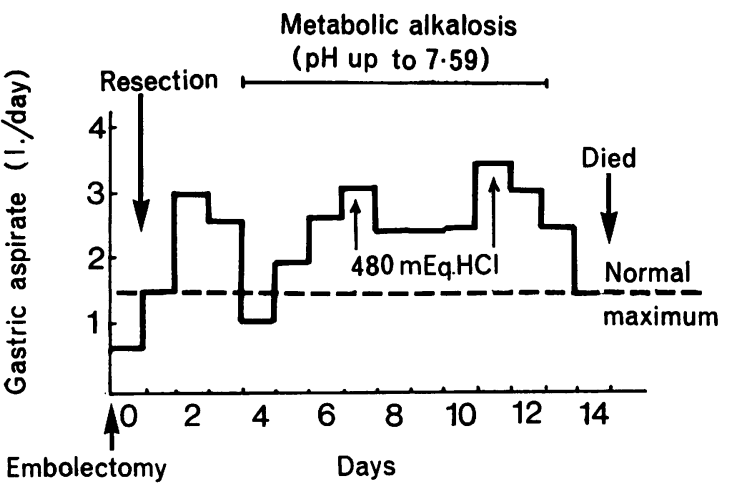

FIG. 1. Daily gastric aspirates from case 1, showing a persistent hypersecretory state associated with a metabolic alkalosis. This patient also had a low serum potassium level $(<3$ m-equiv/l).

onset and the duration of the hypersecretory trend. Each patient is represented by a horizontal line. In each instance the onset was within four days of resection and persisted in one case for up to $\mathbf{4 0}$ days. Usually, however, it was a transient phenomenon lasting less than 14 days.

Liver function Perhaps the most striking findings as a result of the liver function studies (Table III) were that six of the 19 patients had elevated bilirubin levels and each of these developed a hypersecretory state. There was no evidence that the remaining patients had abnormal liver function, or jaundice. It is here that the weakness of a retrospective study becomes apparent since Table III summarizes all the liver function tests carried out on these patients. However, it is suggested that gastric hypersecretion after massive intestinal resection is fairly well correlated with evidence of hepatic parenchymal cell damage and elevated bilirubin levels.

Gastric function Table IV shows the results of seven gastric function studies in the survivors; none of these patients showed evidence of hypersecretion in the immediate postoperative period. The range of the basal output (0.6 to 5.6 m-equiv hydrochloric

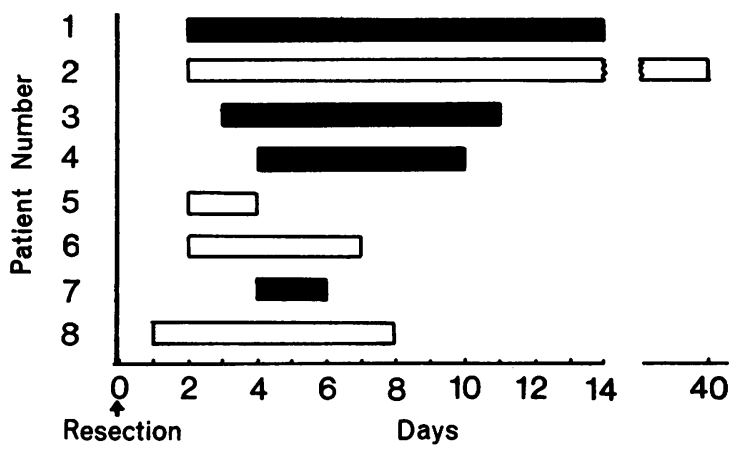

FIG. 2. Onset and duration of the hypersecretory phase. Patients 1 to 8 are represented as horizontal bars indicating the postoperative period during which massive aspirates occurred. Dark bars denote patients who died.

\section{TABLE IV}

RESULTS OF GASTRIC FUNCTION STUDIES IN SURVIVORS AFTER MASSIVE INTESTINAL RESECTION

\begin{tabular}{llc} 
Case No. & $\begin{array}{l}\text { Basal Rate } \\
\text { (m-equiv/hour) }\end{array}$ & $\begin{array}{l}\text { Peak Acid } \\
\text { Output }\end{array}$ \\
\hline 10 & 3.6 & 32.5 \\
11 & 4.7 & 19.7 \\
12 & 0.6 & 11.2 \\
13 & 3.8 & 15.4 \\
14 & 5.6 & 28.1 \\
16 & 1.1 & 5.0 \\
17 & 1.1 & 24.0
\end{tabular}

acid per hour) is within the normal range for our laboratory as is the peak acid output (5 to $32.5 \mathrm{~m}$-equiv hydrochloric acid per hour). There is no evidence that survivors after massive resection, in whom there was no evidence of postoperative hypersecretion, have hypochlorhydria or a raised basal secretory rate.

DOG STUDIES The tests of gastric functions gave the following results.

Daily acid output Table V shows the daily acid output before and after $75 \%$ intestinal resection in the Heidenhain and Pavlov pouch dogs. One dog,

TABLE III

RESULTS OF LIVER FUNCTION STUDIES

\begin{tabular}{|c|c|c|c|c|c|c|c|c|c|}
\hline $\begin{array}{l}\text { Case } \\
\text { No. }\end{array}$ & $\begin{array}{l}\text { Maximum } \\
\text { Aspirate } \\
\text { (ml/day) }\end{array}$ & $\begin{array}{l}\text { Bilirubin } \\
(\mathrm{mg} / 100 \mathrm{ml})\end{array}$ & $\begin{array}{l}\text { SGPT } \\
\text { Units }\end{array}$ & $\begin{array}{l}\text { SGOT } \\
\text { Units }\end{array}$ & $\begin{array}{l}\text { Alkaline } \\
\text { Phosphatase } \\
\text { (King- } \\
\text { Armstrong } \\
\text { Units) }\end{array}$ & $\begin{array}{l}\text { Thymol } \\
\text { Flocculation }\end{array}$ & $\begin{array}{l}\text { Zinc } \\
\text { Turbidity } \\
\text { (Normal } \\
1-6)\end{array}$ & $\begin{array}{l}\text { Lowest } \\
\text { Albumin Level } \\
(\mathrm{g} / 100 \mathrm{ml})\end{array}$ & $\begin{array}{l}\text { Lowest } \\
\text { Globulin Level } \\
(\mathrm{g} / 100 \mathrm{ml})\end{array}$ \\
\hline 1 & 4,160 & $2 \cdot 6-4 \cdot 7$ & 850 & 660 & - & - & - & $2 \cdot 1$ & $1 \cdot 6$ \\
\hline 2 & 3,800 & $1 \cdot 2-9 \cdot 1$ & 22 & 42 & 16.9 & - & - & 2.4 & 3.0 \\
\hline 4 & 2,950 & 3.4 & - & - & 5 & $+t+$ & - & - & - \\
\hline 6 & 3,800 & $1 \cdot 2$ & - & - & - & ++ & - & 3.4 & $2 \cdot 2$ \\
\hline 7 & 3,010 & $16 \cdot \overline{1}$ & $120+$ & $200+$ & 15 & - & - & $3 \cdot 1$ & 2.9 \\
\hline .8 & 1,985 & 6.6 & - & - & $7 \cdot 5$ & - & 9 & - & - \\
\hline
\end{tabular}


TABLE V

DAILY ACID OUTPUT FROM HEIDENHAIN AND PAVLOV POUCHES BEFORE AND AFTER MASSIVE RESECTION

\begin{tabular}{|c|c|c|c|c|c|c|}
\hline $\begin{array}{l}\text { Type of } \\
\text { Pouch }\end{array}$ & $\begin{array}{l}\text { Dog } \\
\text { No. }\end{array}$ & $\begin{array}{l}\text { Collection before and } \\
\text { after Resection }\end{array}$ & $\begin{array}{l}\text { No. of } \\
\text { Observations }\end{array}$ & $\begin{array}{l}\text { Mean } \\
\text { (m-equiv/day) }\end{array}$ & $\begin{array}{l}\text { Change } \\
\text { (m-equiv/day) }\end{array}$ & $\mathbf{P}$ \\
\hline \multirow[t]{5}{*}{ Heidenhain } & 102 & $\begin{array}{l}\text { Before } \\
\text { After }\end{array}$ & $\begin{array}{l}31 \\
29\end{array}$ & $\begin{array}{r}4 \cdot 88 \\
12 \cdot 71\end{array}$ & $+7 \cdot 38$ & $<0.001$ \\
\hline & 103 & $\begin{array}{l}\text { Before } \\
\text { After }\end{array}$ & $\begin{array}{r}22 \\
9\end{array}$ & $\begin{array}{r}8.33 \\
21.06\end{array}$ & +12.73 & $<0.001$ \\
\hline & 105 & $\begin{array}{l}\text { Before } \\
\text { After }\end{array}$ & $\begin{array}{l}34 \\
27\end{array}$ & $\begin{array}{r}9.95 \\
13.00\end{array}$ & +3.05 & $<0.25$ \\
\hline & 106 & Before & $\begin{array}{l}24 \\
30\end{array}$ & $\begin{array}{r}7 \cdot 87 \\
14.95\end{array}$ & +7.06 & $<0.001$ \\
\hline & 114 & $\begin{array}{l}\text { Before } \\
\text { After }\end{array}$ & $\begin{array}{l}23 \\
31\end{array}$ & $\begin{array}{l}7 \cdot 23 \\
6 \cdot 43\end{array}$ & -0.8 & $<0.25$ \\
\hline \multicolumn{7}{|l|}{ Pavlov } \\
\hline & 121 & $\begin{array}{l}\text { Before } \\
\text { After }\end{array}$ & $\begin{array}{l}26 \\
17\end{array}$ & $\begin{array}{l}10 \cdot 3 \\
34 \cdot 9\end{array}$ & $+24 \cdot 6$ & $<0.001$ \\
\hline & 122 & Before & 26 & $26 \cdot 7$ & $+13 \cdot 6$ & $<0.001$ \\
\hline & & After & 13 & $40 \cdot 3$ & & \\
\hline & 123 & $\begin{array}{l}\text { Before } \\
\text { After }\end{array}$ & $\begin{array}{l}33 \\
13\end{array}$ & $\begin{array}{r}7 \cdot 1 \\
13 \cdot 8\end{array}$ & +6.7 & $<0.01$ \\
\hline
\end{tabular}

no. 114, did not show an increased acid output; the reason for this is not apparent from this study. The remainder of the animals markedly increased their daily output.

Postcibal response Figure 3 shows the results of test meals in the Heidenhain and Pavlov pouch dogs before and after resection. The control curves are the mean of 35 studies (Heidenhain pouch) and eight studies (Pavlov pouch) and 22 and eight studies respectively in the resected animals. Each point represents the mean hourly output for the group, the standard error being shown as vertical bars.

Intestinal resection prolongs the acid response after food. In the Heidenhain pouch dogs the peak output has moved from the third hour to the fourth hour, but the peaks are not statistically different. The post-resection curve follows the normal pattern for the first three hours, continues to rise, and shows a statistically significant difference from controls in the sixth hour (fifth hour $0.1>P>0.05$, sixth hour $0.01>P>0.001$ ). The differences in the acid output between the total six-hour period before and after resection (1.8 m-equiv and $2.5 \mathrm{~m}$-equiv) is not statistically significant. In the Pavlov pouch dogs a similar curve is seen, acid output in the resected dogs being significantly greater than control in the fourth, fifth, and sixth hours (fourth hour $0.05>P>0.02$, fifth hour $0.01>P>0.001$, sixth hour $P<0.001$ ).

Basal secretory rate In five dogs there was a small increase in the basal rate of secretion, in two a decrease, and in one no change (Table VI). Statistical analysis of the group and of individual dogs shows no statistical significance in these changes $(t$ test on difference of means to zero, $t \mathbf{1 \cdot 7 1} ; \mathrm{P}>0 \cdot 10$.)

\section{HEIDENHAIN pouches PAVLOV pouches}

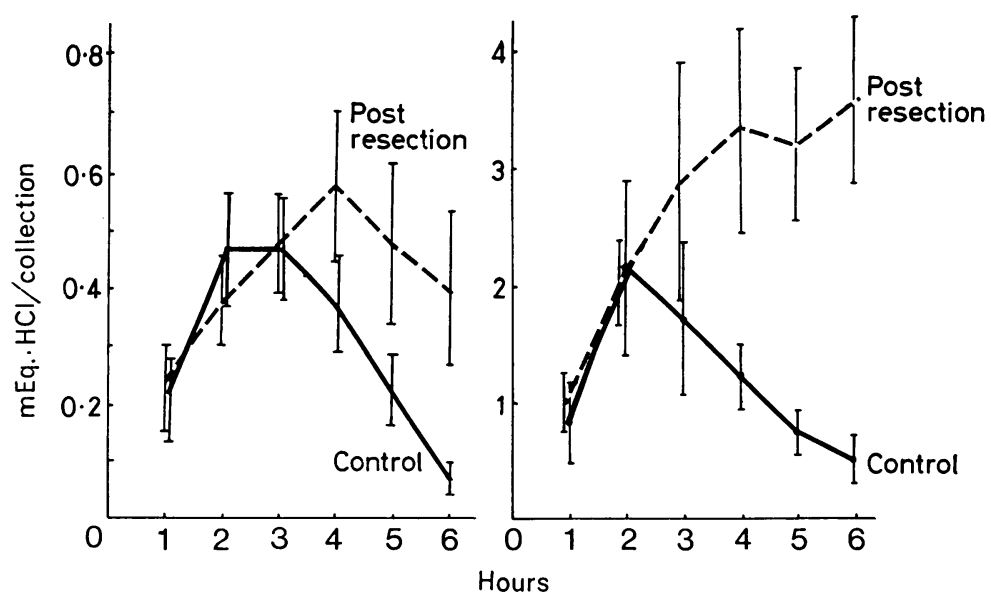

FIG. 3. Postcibal acid output in Heidenhain and Pavlov pouch dogs before (control) and after $75 \%$ intestinal resection. The curves are the means for all dogs in the groups. The standard error is shown as vertical bars. 
TABLE VI

EFFECT OF INTESTINAL RESECTION ON THE BASAL SECRETORY RATE AND RESPONSE TO HISTAMINE

\begin{tabular}{|c|c|c|c|c|c|c|}
\hline $\begin{array}{l}\text { Type of } \\
\text { Pouch }\end{array}$ & $\begin{array}{l}\text { Dog } \\
\text { No. }\end{array}$ & $\begin{array}{l}\text { Collections } \\
\text { before and after } \\
\text { Resection }\end{array}$ & $\begin{array}{l}\text { Basal Rate } \\
\text { (m-equiv HCl/hour) }\end{array}$ & $\begin{array}{l}\text { Change } \\
\text { (m-equiv HCl/hour) }\end{array}$ & $\begin{array}{l}\text { Peak Histamine Resp } \\
\text { (m-equiv HCl/hour) }\end{array}$ & $\begin{array}{l}\text { ponse } \\
\text { Change } \\
\text { (m-equiv } \mathrm{HCl} / \text { hour) }\end{array}$ \\
\hline \multicolumn{7}{|c|}{ Heidenhain } \\
\hline & 102 & $\begin{array}{l}\text { Before } \\
\text { After }\end{array}$ & $\begin{array}{l}0.01 \\
0.08\end{array}$ & +0.07 & $\begin{array}{l}1 \cdot 12 \\
1.69\end{array}$ & +0.48 \\
\hline & 103 & $\begin{array}{l}\text { Before } \\
\text { After }\end{array}$ & $\begin{array}{l}0.01 \\
0.24\end{array}$ & +0.23 & $\begin{array}{l}1.02 \\
4.03\end{array}$ & +3.01 \\
\hline & 105 & $\begin{array}{l}\text { Before } \\
\text { After }\end{array}$ & $\begin{array}{l}0.02 \\
0.01\end{array}$ & -0.01 & $\begin{array}{l}1.61 \\
1.21\end{array}$ & -0.4 \\
\hline & 106 & $\begin{array}{l}\text { Before } \\
\text { After }\end{array}$ & $\begin{array}{l}0.04 \\
0.05\end{array}$ & +0.01 & $\begin{array}{l}2 \cdot 36 \\
2 \cdot 67\end{array}$ & $+0 \cdot 31$ \\
\hline & 114 & $\begin{array}{l}\text { Before } \\
\text { After }\end{array}$ & $\begin{array}{l}0.01 \\
0.01\end{array}$ & 0 & $\begin{array}{l}3 \cdot 13 \\
4 \cdot 9\end{array}$ & $+1 \cdot 77$ \\
\hline \multicolumn{7}{|l|}{ Pavlov } \\
\hline & 121 & $\begin{array}{l}\text { Before } \\
\text { After }\end{array}$ & $\begin{array}{l}1 \cdot 2 \\
1.7\end{array}$ & +0.5 & & \\
\hline & 122 & $\begin{array}{l}\text { Before } \\
\text { After }\end{array}$ & $\begin{array}{l}2 \cdot 1 \\
1 \cdot 3\end{array}$ & -0.8 & & \\
\hline & 123 & $\begin{array}{l}\text { Before } \\
\text { After }\end{array}$ & $\begin{array}{l}0.01 \\
0.02\end{array}$ & +0.02 & & \\
\hline
\end{tabular}

Histamine response In four dogs there was an increase in the peak response to histamine $(0 \cdot 1 \mathrm{mg} / \mathrm{kg}$ histamine phosphate) and in one a decrease (Table VI). The greatest increase $(\operatorname{dog} 103+3.01$ m-equiv/ hour) is not statistically significant $(\mathrm{t} 2 \cdot 11, \mathrm{P}>0 \cdot 10)$. Comparison of the group before and after resection shows a mean increase of $1.03 \mathrm{~m}$-equiv/hour which again is not statistically significant $(P>0 \cdot 1)$.

\section{DISCUSSION}

CLINICAL STUDY Postoperative gastric hypersecretion was observed in eight of 19 patients after massive small intestinal resection. This was evident as an increase in the basal secretory rate beginning within four days of resection. The duration of the hypersecretion was usually less than two weeks but in one instance it persisted for $\mathbf{4 0}$ days.

These was no relationship between the length of resected intestine and the appearance of hypersecretion. This suggests that factors other than the removal of bowel are responsible for the phenomenon. In the following paragraphs consideration is given to possible causes of hypersecretion which may be important if resection is not the prime cause. These are the effects on gastric secretion of surgery, infection, acid base disturbances, and deranged liver function.

Dragstedt et al (1956) found a slight increase in the basal rate of gastric secretion after operation in six of 13 patients studied. They suggested that this was due to an increase of vagal tone as it was not apparent in patients after vagotomy. 'Surgical stress' is known to increase adrenal, medullary, and cortical secretions (Hume, 1957). The effects of ACTH and corticoids on human gastric secretion have been conflicting, some showing a slight increase in secretion (Gray, Benson, Reifenstein, and Spiro, 1951) and others a decrease (Hirschowitz, Streeten, Pollard, and Boldt, 1955). It is thought unlikely, therefore, that surgery or 'surgical stress' would cause hypersecretion of the magnitude seen in these patients.

Peritonitis, and in some instances septicaemia, complicated the postoperative course of some patients; however, extensive studies over the years have repeatedly shown that bacterial infection suppresses gastric secretion (Bandes, Hollander, and Bierman, 1948; Blickenstaff and Grossman, 1950). Any coincident infection would therefore be expected to suppress the hypersecretion.

Four of the patients with hypersecretion had a marked metabolic alkalosis and low serum potassium levels. Alkalosis has been shown to decrease the basal acid output (Byers, Jordan, and Maren, 1961) and a low serum potassium is known to suppress gastric secretion (Carrone and Cooke, 1953; Muro, Rowinski, Calaresu, and Fraghi, 1961). Depletion of hydrochloric acid by continuous gastric aspiration has, however, been shown to induce a metabolic alkalosis and simultaneously increase renal potassium losses, leading to a hypokalaemic alkalosis (Needle, Kaloyanides, and Schwartz, 1964; Kassirer and Schwartz, 1966). The electrolyte changes encountered in our patients are therefore thought to be secondary to the hydrochloric acid loss.

There was a correlation in this series of patients between biochemical evidence of liver damage and 
gastric hypersecretion. Is it possible to link intestinal resection, particularly of gangrenous gut in a shocked patient, with hepatic cell injury? In 1932 Cole and Elman showed in dogs that strangulated loops of small intestine caused centrilobular liver cell necrosis without evidence of bacterial invasion of the liver. Resection of normal intestine from dogs has, however, been shown to have no effect on liver function or histology (Landor and Baker, 1964; Frederick et $a l, 1965)$. Boyce (1941) found that of 715 patients with intestinal obstruction, 23 had biochemical evidence of liver damage. Other factors such as myocardial infarction and hypotension are known to result in liver damage (Sherlock, 1951; Schalm and Hoogenboom, 1952). From this evidence it seems possible that a combination of factors such as infarcted or strangulated intestine, and liver anoxia due to hypotension could lead to liver damage of a type noted in our patients.

Is it possible that the liver damage is the cause of the hypersecretion? Again a link has been established. Pikula and Dunphy (1959) demonstrated hepatic cell damage after bile duct ligation and more recently Silen, Hein, Albo, and Harper (1963) have produced gastric hypersecretion by bile duct ligation in dogs. These experiments would suggest that hepatic cellular damage causes gastric hypersecretion. Apparently conflicting evidence (Orloff and Windsor, 1966) has shown that liver damage in dogs results in gastric hyposecretion. However, in this experiment the liver damage was produced by chronic venous congestion. It is now thought possible that acute liver damage and chronic liver damage have different effects on gastric secretion which could account for the difference between this and other reports (Skillman, Silen, Harper, Neely, and Simmons, 1961; Hein, Silen, Skillman, and Harper, 1963). Recent studies have shown that portal vein infusions of small doses of carbon tetrachloride $(0 \cdot 1 \mathrm{mg} / \mathrm{kg}$ body weight daily), in dogs with Heidenhain pouches, produce gastric hypersecretion within seven to 10 days (Baddeley, 1968). The hypersecretion was coincident with biochemical evidence of liver failure and was evident as an increase in the basal secretory rate. The hypersecretion was thought to be due to acute damage of the hepatic parenchyma with a coincident release of secretory agents. Previous workers have also suggested that acute hepatic injury releases histamine from the liver (Anrep and Barsoum, 1953; Anrep, Barsoum, and Talaat, 1953).

It seems likely that release of a secretagogue, possibly histamine, from the acutely damaged liver is the cause of the elevated basal secretory rate described in these patients with hypersecretion.

The gastric function studies carried out on the survivors in Table IV show that both the basal rate and the peak acid output are within the normal range after massive resection. This suggests that no permanent changes occur in the parietal cell population after resection. These findings do not lend support to the view that patients who survive massive resection of the small intestine without evidence of hypersecretion have hypochlorhydria or achlorhydria (Oxborne et al, 1966). In addition there would seem to be no rationale in performing vagotomy and pyloroplasty at the same time as resection as suggested by Osborne, Sizer, Frederick, and Zamcheck (1967).

EXPERIMENTAL STUDY The dog studies show that massive resection increases the 24-hour acid output but there is no significant change in the basal secretory rate. These results agree with those of Osborne et al (1966). Others (Reul and Ellison, 1966) had difficulty in attaining basal rates after a 24-hour fast in Heidenhain pouch dogs. The results of our study were obtained after a 31-hour fast when basal conditions had been reached. The Pavlov pouch results would seem to exclude the possibility that intestinal resection causes increased vagal activity. Such a mechanism could have accounted for the raised basal rate seen in the patients. By beginning basal rate measurements within one week of the resection in the dogs it is felt unlikely that an acute hypersecretory state as seen in the human subjects has been missed.

The postcibal acid secretion is the only significant difference between the pouch dogs before and after resection (Fig. 3). This confirms tentative suggestions made by Reul and Ellison (1966). In both the Heidenhain and Pavlov pouch dogs there is a prolonged and enhanced response to feeding. During the fourth and fifth hours after the meal, when normally acid secretion is diminishing, there is continued secretory activity. At this time food has usually reached the small intestine and inhibitory pathways of gastric secretion have been activated. In the animals studied the antrum and duodenum were intact suggesting that primarily small intestinal inhibitory activity is compromised by resection. Delay in gastric emptying has been suggested as a cause of the phenomenon but the results of other studies (Landor and Baker, 1964; Osborne et al, 1966) have failed to show a decreased rate of emptying after massive small intestinal resection. The results of antrectomy, vagotomy, and metabolic studies on our dogs (Windsor, 1968a) has led to the belief that the main factor is the loss of a fat-stimulated intestinal inhibitory agent, probably enterogastrone, which normally modifies the antral phase of secretion. 
GENERAL It remains probable that a hypersecretory state with similar characteristics to that seen in dogs exists in patients after resection. Studies on infants in which the secretory rate of the stomach after massive resection was measured three hours after feeding lend support to this view (Avery, Randolph, and Weaver, 1966). These workers showed a highly significant increase in acid output at this time when these patients were compared with normal infants. This correlates well with the findings of this investigation, that the maximum rate of secretion after resection is delayed after feeding (Fig. 3). The tests of gastric function with pentagastrin and histamine performed on patients and dogs showed no abnormalities after resection; this would be as expected since they give no information on defects of intestinal inhibition.

The clinical and experimental models studied were somewhat different; in man diseased or ischaemic bowel was resected, while in dogs the intestine removed was healthy. Further studies in dogs in which ischaemic intestine is resected would be valuable in confirming the conclusions reached from the clinical investigations. Despite these differences the results do not support the view that vagotomy and pyloroplasty should be performed at the same time as massive resection in patients (Craig and Stewart, 1960; Duval, 1964; Osborne et al, 1967; Leonard, Levine, Wittner, Buchwald, and Varco, 1967). The hypersecretory phase was usually transient, lasting less than two weeks in most instances, and there was no evidence of an increased parietal cell count or elevated basal rate of secretion after resection. In addition we found no evidence that the massive fluid, electrolyte, and hydrogen ion losses, if aggressively treated, contributed to the cause of death in our patients. Studies in dogs with Heidenhain pouches and Pavlov pouches have shown that the postcibal hypersecretion is enhanced by vagotomy and pyloroplasty to the main stomach (Windsor, 1968a, 1968b). In addition, faecal fat measurements gave no support to the view that malabsorption may be prevented by vagotomy and pyloroplasty (Windsor, 1968a).

I should like to thank the Medical Research Council for financial support for the experimental part of this study, and the consultant surgeons in the West Midlands Region who supplied the details of the cases presented.

\section{REFERENCES}

Aber, G. M., Ashton, F., Carmalt, M. H. B., and Whitehead, T. P. (1967). Gastric hypersecretion following massive small-bowel resection in man. Amer. J. dig. Dis., 12, 785-794.

Allen, J. G. (1959). The Physiology and Treatment of Peptic Ulcer, p. 5. University of Chicago Press, U.S.A.

Anrep, G. V., and Barsoum, G. S. (1953). Blood histamine in experimental obstruction of the common bile duct. $J$. Physiol. (Lond.), 120, 427-430. $\longrightarrow$, and Talaat, M. (1953). Release of histamine by the liver. Ibid, 120, 419-426.

Avery, G. B., Randolph, J. G., and Weaver, T. (1966). Gastric response to specific disease in infants. Pediatrics, 38, 874-878.

Bandes, J., Hollander, F., and Bierman, W. (1948). The effect of physically induced pyrexia on gastric acidity. Gastroenterology, 10, 697-707.

Baddeley, R. M. (1968). Gastric secretion in human and experimental liver disease. Ch.M. Thesis, Birmingham University.

Blickenstaff, D., and Grossman, M. I. (1950). A quantitative study of the reduction of gastric acid secretion associated with pyrexia. Amer. J. Physiol., 160, 567-571.

Boyce, F. F. (1941). The Role of the Liver in Surgery, pp. 17-20. Thomas, Springfield, Ill.

Byers, F. M., Jordan, P. H., Jr, and Maren, T. H. (1961). Effects of acetazolamide (diamox) and of metabolic acidosis and alkalosis upon gastric acid secretion in dogs. Surg. Forum, 12, 289-291.

Carone, F. A., and Cooke, R. E. (1953). Effect of potassium deficiency on gastric secretion in the rat. Amer. J. Physiol., 172, 684-688.

Cole, W. H., and Elman, R. (1932). Pathological changes in liver accompanying intestinal obstruction and strangulation. Proc. Soc. exp. Biol. (N.Y.), 29, 1274-1275.

Craig, T. V., and Stewart, W. R. C. (1960). Massive bowel resection in a patient with 75 per cent gastrectomy. Surgery, 48, 678-681.

Dè Vito, R. V., and Harkins, H. N. (1959). Techniques in Heidenhain pouch experiments. J. appl. Physiol., 14, 138-139.

Dragstedt, L. R., Ragins, H., Dragstedt, L. R., II, and Evans, S. O., Jr (1956). Stress and duodenal ulcer. Ann. Surg., 144, 450-463. Woodward, E. R., Storer, E. H., Oberhelman, H. A., Jr, and Smith, C. A. (1950). Quantitative studies on the mechanism of gastric secretion in health and disease. Ibid, 132, 626-640.

Duval, M. K., Jr (1964). Discussion to Frederick, P. L., and Craig, T. V. The effect of vagotomy and pyloroplasty on weight loss and survival of dogs after massive intestinal resection. Surgery, $56,141-142$.

Frederick, P. L., Sizer, J. S., and Osborne, M. P. (1965). Relation of massive bowel resection to gastric secretion. New Engl. J. Med., 272, 509-514.

Gray, S. J., Benson, J. A., Jr, Reifenstein, R. W., and Spiro, H. M. (1951). Chronic stress and peptic ulcer. I. Effect of corticotrophin (ACTH) and cortisone on gastric secretion. J. Amer. med. Ass., 147, 1529-1537.

Grundberg, A. B., Lopez, A. S., and Dragstedt, L. R., II (1967). Effect of intestinal reversal and massive resection on gastric secretion. Arch. Surg., 94, 326-329.

Haymond, H. E. (1935). Massive resection of the small intestine; an analysis of 257 collected cases. Surg. Gynec. Obstet., 61, 693-705.

Hein, M. F., Silen, W., Skillman, J. J., and Harper, H. A. (1963). Effect of portacaval shunting on gastric secretion in cirrhotic dogs. Gastroenterology, 44, 637-641.

Hirschowitz, B. I., Streeten, D. H. P., Pollard, H. M., and Boldt, H. A., Jr (1955). Role of gastric secretions in activation of peptic ulcers by corticotrophin. J. Amer. med. Ass., 158, 27-32.

Hume, D. M. (1957). The secretion of epinephrine, nor-epinephrine and corticosteroids in the adrenal venous blood of the dog following single and repeated trauma. Surg. Forum, 8, 111-115.

Kassirer, J. P., and Schwartz, W. B. (1966). The response of normal man to selective depletion of hydrochloric acid. Amer. J. Med., 40, 10-18.

Kerr, G., Elliott, D. W., and Endahl, G. L. (1968). Effect of antrectomy on gastric acid hypersecretion induced by isolation of the proximal small bowel. Amer. J. Surg., 115, 157-164.

Landor, J. H., and Baker, W. K. (1964). Gastric hypersecretion produced by massive small bowel resection in dogs. J. surg. Res., 4, 518-522.

Leonard, A. S., Levine, A. S., Wittner, R., Buchwald, H., and Varco, R. L. (1967). Massive small-bowel resections. Operative and dietary management. Arch. Surg., 95, 429-435.

Muro, P. de, Rowinski, P., Calaresu, I., and Fraghi, A. (1961). The importance of potassium in the mechanism of gastric hydrochloric acid secretion. Acta med. scand., 170, 403-410.

Needle, M. A., Kaloyanides, G. J., and Schwartz, W. B. (1964). The effects of selective depletion of hydrochloric acid on acid-base and electrolyte equilibrium. J. clin. Invest., 43, 1836-1846.

Orloff, M. J., and Windsor, C. W. O. (1966). Effect of portacaval shunt on gastric acid secretion in dogs with liver disease, portal hypertension and massive ascites. Ann. Surg., 164, 69-80. 
Osborne, M. P., Frederick, P. L., Sizer, J. S., Blair, D., Cole, P., and Thum, W. (1966). Mechanism of gastric hypersecretion following massive intestinal resection. Clinical and experimental observations. Ibid, 164, 622-634.

_- Sizer, J., Frederick, P. L., and Zamcheck, N. (1967). Massive bowel resection and gastric hypersecretion. Amer. J. Surg., 114, 393-397.

Perry, J. F., Jr, Salmon, P., Griffen, W. O., Jr, Root, H. D., and Wangensteen, O. H. (1959). A simple technique for preparing vagally innervated gastric pouches in dogs. Surgery, 45, 937-940.

Pikula, J. V., and Dunphy, J. E. (1959). Some effects of stenosis of the terminal common bile duct on the biliary tract and liver. New Engl. J. Med., 260, 315-318.

Pullan, J. M. (1959). Massive intestinal resection. Proc. roy. Soc. Med., $52,31-37$.

Reul, G. J., and Ellison, E. H. (1966). Effect of 75 per cent distal small bowel resection on gastric secretion. Amer. J. Surg., 111, 772-776.
Schalm, L., and Hoogenboom, W. A. H. (1952). Blood bilirubin in congestive heart failure. Amer. Heart J., 44, 571-580.

Sherlock, S. (1951). The liver in heart failure. Brit. Heart J., 13, 273-293.

Silen, W., Hein, M. F., Albo, R. J., and Harper, H. A. (1963). Influence of liver upon canine gastric secretion. Surgery, 54, 29-36.

Skillman, J. J., Silen, W., Harper, H. A., Neely, J. C., and Simmons, E. L. (1961). Effect of hepatocellular injury on gastric secretion in dogs. Surg. Forum, 12, 276-277.

Westerheide, R. L., Elliott, D. W., and Hardacre, J. M. (1965). The potential of the upper small bowel in regulating acid secretion. Surgery, 58, 73-83.

Windsor, C. W. O. (1968a). Gastric secretion after massive intestinal resection. A clinical and experimental study. Ch.M. Thesis, Birmingham University.

- (1968b). Gastric secretion following massive small intestinal resection. (Abstr.) Brit.J. Surg., 55, 392.

Wright, S. (1952). Applied Physiology, 9th ed., p. 781. Oxford University Press, London. 